UDC 629.3.027.5

\title{
MATHEMATICAL MODEL OF PRESSURE CHANGE IN AUTOMOBILE PNEUMATICAL TIRE DEPENDING ON OPERATING TEMPERATURE
}

\author{
Orysenko Oleksandr ${ }^{1}$, Nesterenko Mykola ${ }^{2}$, Vasyliev Oleksiy ${ }^{3 *}$, Rohozin Ivan ${ }^{4}$ \\ ${ }^{1}$ Poltava National Technical Yuri Kondratyuk University https://orcid.org/0000-0003-3103-0096 \\ ${ }^{2}$ Poltava National Technical Yuri Kondratyuk University https://orcid.org/0000-0002-8961-2147 \\ ${ }^{3}$ Poltava National Technical Yuri Kondratyuk University https://orcid.org/0000-0002-9914-5482 \\ ${ }^{4}$ Poltava National Technical Yuri Kondratyuk University https://orcid.org/0000-0002-9052-4806 \\ *Corresponding author E-mail: a.s.vasiliev.76@gmail.com
}

\begin{abstract}
It has been established that in the process of operation pressure ratings in the tires of many cars differs from those recommended by the production plant. Is leads to performance degradation of tires traveling properties and their loss of life. The pressure excursion from the normative value may be caused either by an error during tire inflation, or by the fact that the difference between the operating temperature and the temperature of the inflating air has not considered. Using athematical-statistical methods of data processing, there has been deduced the mathematical relationship between pressure in the pneumatical tire at the operating temperature and the required pressure of inflating air into the tire, if the temperatures of inflation and operation differ.
\end{abstract}

Keywords: pneumatical tire, inflation pressure, three-level plan, planning matrix, mathematical model.

\section{МАТЕМАТИЧНА МОДЕЛЬ ЗМІНИ ТИСКУ В АВТОМОБІЛЬНІЙ ПНЕВМАТИЧНІЙ ШИНІ ЗАЛЕЖНО ВІД ТЕМПЕРАТУРИ ЕКСПЛУАТАЦІї}

\author{
Орисенко О.В. ${ }^{1}$, Нестеренко М.П. ${ }^{2}$ Васильєв О.С. ${ }^{*}$, Рогозін I.A. ${ }^{4}$ \\ 1,2,3,4 Полтавський національний технічний університет імені Юрія Кондратюка \\ *Адреса для листування E-mail: a.s.vasiliev.76@gmail.com
}

\begin{abstract}
Установлено, що в процесі експлуатації значення тиску в шинах багатьох автомобілів відрізняється від рекомендованого заводом-виробником, що призводить до погіршення експлуатаційних характеристик шин та скорочення їхнього ресурсу. Відомо, що відхилення тиску від нормативного значення може бути спричиненим як похибкою при накачуванні шини, так і неврахуванням різниці між температурою експлуатації та температурою повітря, що закачується. Для проведення дослідження виділено найбільш значуші фактори, які впливають на значення тиску в пневматичній шині, що дозволило скласти рівняння регресії, котре описує явище. Доведено адекватність моделі через визначення похибки та перевірку критеріїв. За допомогою математико-статистичних методів оброки даних виведено математичну залежність між тиском у пневматичній шині при температурі експлуатації та необхідним тиском закачування повітря в шину, якщо температури накачування та експлуатації відрізняються. Отже, отримано математичну залежність, яка дозволяє при відомих температурі в приміщенні, де здійснюється накачування, температурі навколишнього середовища, де буде експлуатуватися шина, та рекомендованому заводом-виробником тиску в шині автомобіля визначити необхідний тиск закачування повітря. Практичним використанням результатів дослідження $€$ значення необхідного тиску накачування залежно від температур.
\end{abstract}

Ключові слова: пневматична шина, тиск накачування, трирівневий план, матриця планування, математична модель. 


\section{Introduction}

The durability of pneumatic tires depends on many factors. Gas pressure in the tire is one of the most important ones. Tires of the same model are installed on the cars of different vehicle brands. The car production plant carries out research and establishes the optimum tire pressure when it has the vehicle maximum loss of life. In the case of pressure excursion from the normative value, the service life of the tire is significantly reduced $[1,2]$. Also, the safety and comfort of the vehicle movement, fuel consumption, durability of a car suspender depend on the tire pressure [3-6].

However, it is known that the pressure does not meet the norm in $60-90 \%$ of tires in operation. Due to the fact, that the pressure does not conform to this norm, there are lost from $6-15 \%$ of the tire life and from 1.5 to $3.0 \%$ of fuel $[7,8]$.

Thus, there is a problem of securing operation of tires with standard pressure. The solution to this problem is complicated by the fact that the pressure change is determined by a large number of different factors. Some factors influence has not been studied sufficiently. Consequently, the crucial task is the study changing gas pressure process in pneumatical tires and the development of measures aimed at the reduction of its deviations from the norm.

\section{Review of research sources and publications}

It the paper it has been established that environmental temperature shift affects the number of technical and operational parameters of a pneumatical tire $[9,10]$. Pressure change is particularly notable.

In the car operation process, the temperature fall can reach several dozens of degrees [7]. For example, during car tire fitting at the premises of a service station or a garage, the air, which temperature is equal to the air temperature in the room, is inflated into the tire. However, outdoors, especially when it is cold, the atmospheric temperature can vary significantly. At the same time, the pressure change takes place in the tire.

\section{Definition of unsolved aspects of the problem}

As it has been noted above, the air temperature inside and outside the tire can vary significantly in different periods of time. It affects the pressure amount, when the air temperature inside the tire is equal with ambient temperature. But the tire pressure is regulated by the manufacturer $[4,11]$. So, there is a need for further study of this effect for the necessary adjustments and description in the mathematical dependencies field [12 $-14]$.

Therefore, the issue of forecasting the pressure change in the tire during its operation at different temperatures has not been solved fully.

\section{Problem statement}

The goal of the research is determination of mathematical relationship between pressure in the pneumatic tire at the operating temperature and the required pressure of inflating air into the tire if the inflating and operation temperatures differ.

\section{Dasic material and results}

To derive a mathematical expression that establishes the functional relationship between the values of standard pressure in the tire, the tire air pressure after finished inflation, the inflating air temperature and the operating temperature for the tire, mathematicalstatistical methods have been used [15].

In the investigation process the following assumptions have been introcced:

- the tire volume does not change with the tire pressure change;

- the composition of the inflating air corresponds to the composition of an air at the sea level;

- the inflation is carried out at an atmospheric pressure of $101.3 \mathrm{kPa}$.

- the main factors of the influence on the standard tire pressure value during operation are: pressure and temperature of the tire inflating air, ambient temperature. Other factors are neglected.

When computations are conducting, the selected factors vary on three levels - middle (main), lower and upper, which are remote from the main level to the same value. This value is called the variation interval (Table 1)

It simplifies the records and subsequent calculations, when the upper level of factors is denoted by the symbol «+», the middle one is $« 0 »$, and the lower one is «», which is equivalent to the transfer of factors to the new code scale.

$$
x_{i}=\frac{X_{i}-X_{i 0}}{\Delta X_{i}},
$$

where $x_{i}$ - value of $i$ th factor on the new code scale;

$X_{i}$ - value of $i$ th factor on a natural scale;

$X_{i 0}-$ main $i$ th factor level;

$\Delta X_{i}-i$ th factor variation interval.

In our case, it assigns the following notations to the factors that consider this calculation:

- the tire air pressure after finished inflation is $x_{1}$

$$
x_{1}=\frac{X_{1}-202.6}{50.65}
$$

- the inflating air temperature is $x_{2}$

$$
x_{2}=\frac{X_{2}-10}{10} ;
$$

- the operating temperature for the tire is $x_{3}$

$$
x_{3}=\frac{X_{3}-0}{30} \text {. }
$$

The matrix of the second order for processing of the computational results has been used, since the studied dependence is unknown [15]. Calculations are made according to the matrix plan, and they are reduced to table 2 . 
Table 1 - The limits of change and factors variation intervals

\begin{tabular}{|l|c|c|}
\hline \multicolumn{1}{|c|}{ Factors } & $\begin{array}{c}\text { The limits of factors } \\
\text { change }\end{array}$ & Variation intervals \\
\hline Tire air pressure after finished inflation $P_{i}, \mathrm{kPa}(\mathrm{atm})$ & $151.95-253.25(1.5-2.5)$ & 50.65 \\
\hline Inflating air temperature $t_{i},{ }^{\circ} \mathrm{C}(\mathrm{K})$ & $0-20(273-293)$ & 10 \\
\hline Ambient temperature when the tire is operated $t_{o},{ }^{\circ} \mathrm{C}(\mathrm{K})$ & $-30-+30(243-303)$ & 30 \\
\hline
\end{tabular}

Table 2 - Three-level plan of the second order with number of factors $k=3\left(N=N_{1}+N_{\alpha}+n_{0}\right)$

\begin{tabular}{|c|c|c|c|c|c|c|c|c|c|c|c|}
\hline \multirow{2}{*}{\multicolumn{2}{|c|}{$\begin{array}{l}\text { Calcula- } \\
\text { tion number }\end{array}$}} & \multicolumn{3}{|c|}{$\begin{array}{l}\text { Planning matrix } \\
\qquad\left(x_{i}\right)\end{array}$} & \multicolumn{3}{|c|}{$\begin{array}{l}\text { Squared variables } \\
\qquad\left(x_{i}^{2}\right)\end{array}$} & \multicolumn{3}{|c|}{ Factor interaction $\left(x_{i} x_{j}\right)$} & \multirow{2}{*}{$\begin{array}{c}\text { Tire pressure, } \mathrm{kPa} \\
y_{i}\end{array}$} \\
\hline & & $x_{1}$ & $x_{2}$ & $x_{3}$ & $x_{1}^{2}$ & $x_{2}^{2}$ & $x_{3}^{2}$ & $x_{1} x_{2}$ & $x_{1} x_{3}$ & $x_{2} x_{3}$ & \\
\hline \multicolumn{2}{|c|}{1} & 2 & 3 & 4 & 5 & 6 & 7 & 8 & 9 & 10 & 11 \\
\hline \multirow{8}{*}{$N_{1}$} & 1 & + & + & + & + & + & + & + & + & + & 266 \\
\hline & 2 & - & + & + & + & + & + & - & - & + & 160 \\
\hline & 3 & + & - & + & + & + & + & - & + & - & 281 \\
\hline & 4 & - & - & + & + & + & + & + & - & - & 169 \\
\hline & 5 & + & + & - & + & + & + & + & - & - & 214 \\
\hline & 6 & - & + & - & + & + & + & - & + & - & 128 \\
\hline & 7 & + & - & - & + & + & + & - & - & + & 225 \\
\hline & 8 & - & - & - & + & + & + & + & + & + & 135 \\
\hline \multirow{6}{*}{$N_{\alpha}$} & 9 & + & 0 & 0 & + & 0 & 0 & 0 & 0 & 0 & 246 \\
\hline & 10 & - & 0 & 0 & + & 0 & 0 & 0 & 0 & 0 & 148 \\
\hline & 11 & 0 & + & 0 & 0 & + & 0 & 0 & 0 & 0 & 192 \\
\hline & 12 & 0 & - & 0 & 0 & + & 0 & 0 & 0 & 0 & 203 \\
\hline & 13 & 0 & 0 & + & 0 & 0 & + & 0 & 0 & 0 & 219 \\
\hline & 14 & 0 & 0 & - & 0 & 0 & + & 0 & 0 & 0 & 175 \\
\hline \multirow{3}{*}{$n_{0}$} & 15 & 0 & 0 & 0 & 0 & 0 & 0 & 0 & 0 & 0 & 196 \\
\hline & 16 & 0 & 0 & 0 & 0 & 0 & 0 & 0 & 0 & 0 & 197 \\
\hline & 17 & 0 & 0 & 0 & 0 & 0 & 0 & 0 & 0 & 0 & 198 \\
\hline
\end{tabular}

The calculated values of the pressure in the tire (columns 11 in Table 2) are obtained on the basis of the air composition data at the sea level [16], and under the condition that the test tire has a volume of 25 liters and the gas mass (inside the test tire) corresponds to the air mass at a pressure of $202.6 \mathrm{kPa}$ and a temperature of $20^{\circ} \mathrm{C}$. The calculation is carried out according to the formula

$$
P_{o}=\frac{M_{a} \cdot R_{d a} \cdot T_{a}}{V_{a}},
$$

where $M_{a}$ - air mass in the tire, $\mathrm{kg}$;

$R_{d a}$ - specific gas constant for dry air [16], $\mathrm{J} /(\mathrm{kg} \cdot \mathrm{K})$;

$T_{a}$ - air temperature in the tire, $\mathrm{K}$;

$V_{a}$ - air volume in the tire, $\mathrm{m}^{3}$.

The table columns 2 - 4 represent a matrix that defines the initial conditions for conducting calculations. The table columns 5, 6 and 7 show the squared variables obtained as a result of the data columns 2 - 4 squaring. They acquire the values +1 or 0 and are marked as $x_{i}^{2}$. Column 8 is obtained by sequential multiplication of factors (variables interaction). For example, for the 8th calculation according to the plan factors $x_{1}=-1$ and $x_{2}$ $=-1$ should be set at the lower level, and the estimated value of the interaction is

$$
x_{1} \cdot x_{2}=(-1) \cdot(-1)=+1 \text {. }
$$

The last column 11 shows the calculation results of the tire pressure at various combinations of factors («outputs»).

The calculation results are processed according to the method [15]. In this case, an algebraic equation is obtained. It reflects the relationship between the properties under investigation and the initial factors.

The algebraic equation in general terms is

$$
\hat{y_{i}}=b_{0}+\sum_{1}^{k} b_{i} x_{i}+\sum_{1}^{k} b_{i i} x_{i}^{2}+\sum_{1}^{k} b_{i j} x_{i} x_{j}
$$

or

$$
\begin{gathered}
\hat{y_{i}=b_{0}+}+b_{1} x_{1}+b_{2} x_{2}+b_{3} x_{3}+b_{11} x_{1}^{2}+b_{22} x_{2}^{2}+b_{33} x_{3}^{2}+ \\
+b_{12} x_{1} x_{2}+b_{13} x_{1} x_{3}+b_{23} x_{2} x_{3},
\end{gathered}
$$

where $i, j=1,2, \ldots, k$ - factors order numbers, $i \neq j$; $\hat{y}_{i}$ - property under investigation - tire pressure; $x_{1}, x_{2}, x_{3}, x_{4}, \ldots x_{k}-$ initial factors;

$b_{0}, b_{1}, b_{2}, \ldots b_{12}, b_{13}, \ldots b_{i j}, b_{i i}$ - equation coefficients.

The coefficients for the plan of the second order with the number of factors $\mathrm{k}=3$ are calculated according to the formulas:

$$
\begin{gathered}
b_{0}=0.1831[0 y]-0,0704 \sum_{1}^{k}[i i y] ; \\
b_{i}=0.1[i y]
\end{gathered}
$$




$$
\begin{gathered}
b_{i i}=-0.0704[0 y]+0.5[i i y]-0.1268 \sum_{1}^{k}[i i y] ; \\
b_{i j}=0.125[i j y],
\end{gathered}
$$

where

$$
\begin{gathered}
{[0 y]=\sum_{1}^{N} y_{u} ;} \\
{[i i y]=\sum_{1}^{N} x_{i u}^{2} y_{u} ;} \\
{[i y]=\sum_{1}^{N} x_{i u} y_{u} ;} \\
{[i j y]=\sum_{1}^{N} x_{i u} x_{j u} y_{u},}
\end{gathered}
$$

according as $i \neq j$;

$y_{u}$ - value of property under investigation in $u$ th calculation;

$x_{i u}$ - value of $i$ th factor in $u$ th calculation;

$x_{j u}$ - value of $j$ th factor in $u$ th calculation $(i \neq j)$;

$N$ - total quantity of calculations in plan (null point included).

After processing the calculations for the adopted plan, the following equation is obtained

$$
\begin{aligned}
& y=197.19+49.2 \cdot x_{1}-5.3 \cdot x_{2}+21.8 \cdot x_{3}-0.26 \cdot x_{1}^{2}+ \\
& +0.24 \cdot x_{2}^{2}-0.26 \cdot x_{3}^{2}-1.25 \cdot x_{1} \cdot x_{2}+5.25 \cdot x_{1} \cdot x_{3}- \\
& -0.75 \cdot x_{2} \cdot x_{3} .
\end{aligned}
$$

Statistical analysis of the quadratic dependence is carried out according to the method [15]. In order to check the significance of the coefficients in the factors, the error is artificially set in the calculations of pressure at the null points within $\pm 5 \%$.

According to the results of calculations at the null points, it is determined:

a) arithmetical average

$$
\bar{y}_{0}=\frac{\sum_{1}^{n_{0}} y_{0 u}}{n_{0}},
$$

where $y_{0 u}$-value of property under investigation at the null point in $u$ th calculation; $n_{0}$ - quantity of calculations at the null point;

b) dispersion at the null point

$$
S_{\bar{y}}^{2}-S_{0}^{2}=\frac{\sum_{1}^{n_{0}}\left(\bar{y}_{0}-y_{0 u}\right)^{2}}{n_{0}-1} ;
$$

c) mean-square deviation

$$
S_{\bar{y}}=S_{0}=\sqrt{S_{0}^{2}}=\sqrt{\frac{\sum_{1}^{n_{0}}\left(\bar{y}_{0}-y_{0 u}\right)^{2}}{n_{0}-1}} ;
$$

d) root-mean-square error in determining coefficients

$$
S\left\{b_{i}\right\}=\frac{S_{\bar{y}}}{\sqrt{N_{1}}} .
$$

The estimated value of Student-test is determined in the following form:

$$
t_{c}=\frac{\left|b_{i}\right|}{S\left\{b_{i}\right\}},
$$

and compare the resulting value $t_{c}$ with the tabular one $t_{t}$ with number of freedom degrees $f_{\bar{y}}$, by which it was determined $S_{\bar{y}}[15]$;

$$
f_{\bar{y}}=n_{0}-1 .
$$

In the case $t_{c}<t_{t}$ with a level of significance $\alpha=0.05$ , the coefficient is taken to be equal to zero, and the corresponding equation member is rejected.

After mathematical processing of data, the refined equation is obtained in the form:

$$
y=197.19+49.2 \cdot x_{1}-5.3 \cdot x_{2}+21.8 \cdot x_{3}+5.25 \cdot x_{1} \cdot x_{3} .
$$

To verify the suitability of the obtained refined equation, the adequacy dispersion is calculated

$$
S_{a d}^{2}=\frac{\sum_{1}^{N_{1}}\left(y_{u}-\hat{y}_{u}\right)^{2}}{N_{1}-m},
$$

where $y_{u}$-value of property under investigation in $u$ th calculation;

$\hat{y}_{u}-$ value of property under investigation in $u$ th calculation, which is calculated according to the refined equation;

$m$ - quantity of significant coefficients together with $b_{0}$.

The estimated value of F-test $F_{p}$ is obtained

$$
F_{p}=\frac{S_{a d}^{2}}{S_{\bar{y}}^{2}}
$$

and compare it with the table value $F$ [15] for degrees of freedom with which were defined $S_{a d}^{2}$ and $S_{y}^{2}$, that is

$$
\begin{aligned}
f_{a d} & =N_{1}-m, \\
f_{\bar{y}} & =n_{0}-1 .
\end{aligned}
$$

In our case $F_{p}<F$, therefore, the equation is considered suitable for calculations.

The resulting equation (17) connects tire pressures at different ambient temperatures and the required inflating pressure at a given temperature of the inflating air.

The designations $P_{o}=y, P_{i}=x_{1}, t_{i}=x_{2}, t_{o}=x_{3}$, are introduced, and the values of $x_{1}, x_{2}, x_{3}$ from the formulas $(2-4)$ are substituted into (17). Then the equation of tire pressure dependence $P_{o}$ from the named factors in the natural form is obtained after simple mathematical transformations:

$$
\begin{aligned}
& P_{o}=5.69+0.971 \cdot P_{i}-0.53 \cdot t_{i}+0,027 \cdot t_{o}+ \\
& +0.0035 \cdot P_{i} \cdot t_{o}
\end{aligned} .
$$

Since, in the conditions of service stations, the practical interest is not so much the pressure in the tire depending on the ambient temperature, but the required pumping pressure depending on the temperature when the pump is carried out. So the value of the pump pressure $P_{i}, \mathrm{kPa}$, is set from the equation (29):

$$
P_{i}=\frac{P_{o}-5.69+0.53 \cdot t_{i}-0.027 \cdot t_{o}}{0.971+0.0035 \cdot t_{o}} .
$$




\section{Conclusion}

As a result of the undertaken research, mathematical relationship between pressure in the pneumatic tire at the operating temperature and the required pressure of inflating air into the tire, if the inflating and operation temperatures differ, has been obtained.
Using the given equation at the known temperature in the room, where the inflation is made, and at the known temperature of the environment, where the tire is operated and at the pressure in the car tire, recommended by the production plant, it is possible to determine the required pressure of air inflation.

\section{References}

1. Лудченко, О.А. (2003). Технічне обслуговування і ремонт автомобілів. Київ: Знання-Прес.

2. Wong, J.Y. (2008). Theory of Ground Vehicles. NYSE: John Wiley \& Sons Inc.

3. Sayers, M.W. \& Han, D. (1996). A Generic Multibody Vehicle Model for Simulating Handling and Braking. Vehicle System Dynamics, 25(1), 599-613.

https://doi.org/10.1080/00423119608969223

4. Taghavifar, H. \& Mardani, A. (2017). Introduction to Off-road Vehicles. Off-road Vehicle Dynamics, 70, 1-16.

https://doi.org/10.1007/978-3-319-42520-7 1

5. d'Ambrosio, S. \& Vitolo, R. (2018). Potential impact of active tire pressure management on fuel consumption reduction in passenger vehicles. Journal of Automobile Engineering, 124-132.

https://doi.org/10.1177/0954407018756776

6. Sina, N., Nasiri, S. \& Karkhaneh, V. (2015). Effects of Resistive Loads and Tire Inflation Pressure on Tire Power Losses and $\mathrm{CO}_{2}$ Emissions in Real-world Conditions. Applied Energy, 157, 974-983.

https://doi.org/10.1016/j.apenergy.2015.04.010

7. Колбасов, А.Ф., Ткаченко, В.П. (2010). Изменение давления в шинах легковых автомобилей при изменении температуры. Современные наукоемкие технологии, 6, 48-51.

8. Захаров, Н.С., Абакумов, Г.В. (2011). Корректирование давления воздуха в шинах при эксплуатации автомобилей зимой. Тюмень: ТюмГНГУ.

9. MacAdam, C. (1986). Development of Driver-Vehicle Steering Interaction Models for Dynamic Analysis. The University of Michigan Transportation Research Institute.

10. Bowen, C.R. \& Arafa, M.H. (2015). Energy Harvesting Technologies for Tire Pressure Monitoring Systems. $A d-$ vanced Energy Materians, 5(7).

https://doi.org/10.1002/aenm.201401787

11. Великанов, Д.П. (1977). Автомобильные транспортные средства. Москва: Транспорт.

12. Polasik, J., Waluś, K.J., Warguła, Ł. (2017). Experimental studies of the size contact area of a summer tire as a function of pressure and the load. Procedia Engineering, $177,347-351$

https://doi.org/10.1016/j.proeng.2017.02.203

13. Caban, J., Droździel, P., Barta, D., Liščák, Š. (2014). Vehicle tire pressure monitoring systems. Diagnostyka, 15(3), 11-14.

14. Singh, I., Singh, B., Sahu, H.., Chauhan, R. \& Sahu, N. (2016). To study on implementation of tyre inflation system for automotive vehicles. Int. Journal of Innovative Research in Science, Engineering and Technology, 5(4), 4708-4711.

https://doi.org/10.15680/IJIRSET.2016.0504014

15. Лецкий, Э., Хартман, К., Шефер, В. (1977). Планирование эксперимента в исследовании технологических прочессов. Москва: Мир

16. Примак, І.Д., Польовий, А.М., Гамалій, І.П. (2008). Сільськогосподарська метеорологія $i$ кліматологія. Біла Церква.
1. Ludchenko, O.A. (2003). Car maintenance and repair. Kiev: Knowledge Press.

2. Wong, J.Y. (2008). Theory of Ground Vehicles. NYSE: John Wiley \& Sons Inc.

3. Sayers,M.W. \& Han, D. (1996). A Generic Multibody Vehicle Model for Simulating Handling and Braking. Vehicle System Dynamics, 25(1), 599-613.

https://doi.org/10.1080/00423119608969223

4. Taghavifar, H. \& Mardani, A. (2017). Introduction to Off-road Vehicles. Off-road Vehicle Dynamics, 70, 1-16.

https://doi.org/10.1007/978-3-319-42520-7 1

5. d'Ambrosio, S. \& Vitolo, R. (2018). Potential impact of active tire pressure management on fuel consumption reduction in passenger vehicles. Journal of Automobile Engineering, 124-132.

https://doi.org/10.1177/0954407018756776

6. Sina, N., Nasiri, S. \& Karkhaneh, V. (2015). Effects of Resistive Loads and Tire Inflation Pressure on Tire Power Losses and $\mathrm{CO}_{2}$ Emissions in Real-world Conditions. Applied Energy, 157, 974-983.

https://doi.org/10.1016/j.apenergy.2015.04.010

7. Kolbasov, A.F. \& Tkachenko, V.P. (2010). Changing the pressure in the tires of a car when the temperature changes. Modern High-Tech Technologies, 6, 48-51.

8. Zakharov, N.S. \& Abakumov, G.V. (2011). Correction of tire pressure when operating cars in the winter. Tyumen: Tyumen.

9. MacAdam, C. (1986). Development of Driver-Vehicle Steering Interaction Models for Dynamic Analysis. The University of Michigan Transportation Research Institute.

10. Bowen, C.R. \& Arafa, M.H. (2015). Energy Harvesting Technologies for Tire Pressure Monitoring Systems. Advanced Energy Materians, 5(7).

https://doi.org/10.1002/aenm.201401787

11. Velikanov, D.P. (1977). Automotive vehicles. Moscow: Transport.

12. Polasik, J., Waluś, K.J., Warguła, Ł. (2017). Experimental studies of the size contact area of a summer tire as a function of pressure and the load. Procedia Engineering, 177, 347-351.

https://doi.org/10.1016/j.proeng.2017.02.203

13. Caban, J., Droździel, P., Barta, D., Lišč́a, Š. (2014). Vehicle tire pressure monitoring systems. Diagnostyka, 15(3), 11-14.

14. Singh, I., Singh, B., Sahu, H., Chauhan, R. \& Sahu, N. (2016). To study on implementation of tyre inflation system for automotive vehicles. Int. Journal of Innovative Research in Science, Engineering and Technology, 5(4), 4708-4711.

https://doi.org/10.15680/IJIRSET.2016.0504014

15. Letsky, E., Hartman, K. \& Schaefer, V. (1977). Planning an experiment in the study of technological processes. Moscow: Peace

16. Primak, I.D., Field, A.M. \& Gamaliy, I.P. (2008). Agricultural Meteorology and Climatology. Bila Tserkva. 